\title{
Prophets, saviours and saints: Symbolic governance and the rise of a transnational metrological field
}

\section{Sotiria Grek ${ }^{1}$}

Published online: 26 June 2020

(c) The Author(s) 2020

\begin{abstract}
Through their collaborative practices of quantification and standardisation in largescale comparative literacy and numeracy surveys, international organisations (IOs) are both constituting new realities and being reconstituted themselves. This article aims to substantiate how the dominance of global measurement regimes has had profound implications for the ways in which IOs such as the United Nations Educational, Scientific and Cultural Organization (UNESCO), the Organisation for Economic Co-operation and Development (OECD) and the World Bank interact, and for the environments these new interrelationships generate. How is one to make sense of this emerging reality? The author of this article examines the interplay of large IOs in their effort to achieve the targets of the United Nations' fourth Sustainable Development Goal (the education-focused SDG 4). She argues that the SDGs are not a stand-alone performance measurement exercise, but are rather organised under the rubric of a much larger monitoring programme with its own internal logic, structure and hierarchies. She demonstrates that SDG 4 represents a significant case of transnational governance of education, and more specifically of the infrastructures and interdependencies of IOs in the construction of education data within the SDGs. Her purpose is to offer insights into the labour and infrastructure involved in the joint production of metrics. Drawing on declarations, agreements and reports as well as empirical findings from a series of interviews she conducted with key actors from all the major IOs and civil society, the author uses Bourdieusian theory to suggest that quantification has facilitated symbolic governance of the education policy field. As a result, the joint effort towards achieving the targets of SDG 4 represents the rise, and to a large degree the dominance, of the influence of the transnational field of measurement in education.
\end{abstract}

Keywords transnational $\cdot$ governance $\cdot$ power $\cdot$ Bourdieu $\cdot$ field $\cdot$ symbolic capital . global · international organisations · Education 2030 - Sustainable Development Goals (SDGs)

Sotiria Grek

Sotiria.Grek@ed.ac.uk

1 School of Social and Political Science, University of Edinburgh, Edinburgh, UK 


\section{Résumé}

Des prophètes, des sauveurs et des saints : la gouvernance symbolique et l'essor de la métrologie transnationale - Par les pratiques collaboratives de quantification et de standardisation qu'elles emploient dans des études comparatives menées à vaste échelle sur l'alphabétisation et la numératie, les organisations internationales composent de nouvelles réalités tout en se trouvant elles-mêmes recomposées. Cet article vise à étayer comment la dominance des modes de mesure mondiaux a eu des conséquences profondes sur les façons dont les organisations internationales comme l'Organisation des Nations Unies pour l'éducation, les sciences et la culture (UNESCO), l'Organisation de coopération et de développement économiques (OCDE) et la Banque mondiale interagissent, et sur les environnements qui naissent de ces interactions. Comment pouvons-nous saisir le sens de cette réalité émergente ? L'auteure de cet article examine les rapports entre les grandes organisations dans les efforts qu'elles mettent en œuvre pour atteindre les cibles du quatrième Objectif de développement durable des Nations Unies (l'ODD 4 axé sur l'éducation). Elle affirme que les ODD ne sont pas un exercice individuel de mesure de performances mais qu'ils entrent plutôt dans la catégorie d'un programme de suivi beaucoup plus large disposant d'une logique, d'une structure et de hiérarchies qui lui sont propres. Elle démontre que l'ODD 4 illustre un cas important de gouvernance internationale de l'éducation et, plus précisément, d'infrastructures des organisations internationales et d'interdépendance entre celles-ci quant à la constitution des données de l'éducation dans le cadre des ODD. Elle entend fournir un aperçu du travail et de l'infrastructure associés à la production conjointe de mesures. En s'appuyant sur des déclarations, des accords et des rapports ainsi que sur les résultats empiriques d'un ensemble d'interviews qu'elle a menées avec des acteurs clés de toutes les grandes organisations et de la société civile, l'auteure puise dans la théorie bourdieusienne pour indiquer que la quantification a facilité la gouvernance symbolique du secteur de la politique de l'éducation. Par conséquent, l'effort conjoint pour atteindre les cibles de l'ODD 4 illustre l'essor et, en grande partie, la dominance de l'influence du secteur transnational de mesure de l'éducation.

\section{Introduction}

Building on the theoretical arsenal of French sociologist Pierre Bourdieu (1977, 1986, 1990, 1993, 2000, 2014), as well as the sociology of quantification (Desrosieres 1998; Espeland and Stevens 2008), this article examines the symbolic governance of the transnational education policy field. ${ }^{1}$ Since the early 2000 s, the rise and dominance of large-scale international comparative assessments of education

\footnotetext{
1 The concept of symbolic governance is explained in more detail later on in this introduction. For now, in a nutshell, in this context, the term refers to the governing effect that numbers have in bringing together national and organisational storylines on the status of education, the actors who employ these storylines and the practices they apply to exert their influence in the field of measurement (Grek 2020a).
} 
performance have given international organisations $(\mathrm{IOs})^{2}$ a central position in processes of standardisation, de-contextualisation and performance management through the quantification of education policy. As a result, IOs have been instrumental in commensurating - and therefore transforming - education as a global field of measurement.

Nevertheless, despite the burgeoning number of publications on the global phenomenon of "governing by numbers", our understanding of the relationship between the politics of measurement and how transnational governance comes into being is less well examined. Due to the fluidity and complexity of intense cross-boundary networks and "soft" regulation regimes ${ }^{3}$ that dominate the transnational space, transnational governance is a particularly productive field of enquiry into the role of quantification as an infrastructure that facilitates governance (Djelic and SahlinAndersson 2006). Thus, a central focus of this article is the examination of the politics of quantification through the prism of the political work of the actors (Lagroye 1997) involved in the collection and validation of country data as part of global education performance monitoring (Grek 2020b). By "political work" I mean actors' practices undertaken in order to develop and manage the interdependencies between internal (upstream) and external (downstream) relationships, as well as personal ideas, values and interests;

political work takes place through and across a range of configurations of actors who compete to construct alliances - political enterprises - that are capable of winning the negotiations they are involved in (Jullien and Smith 2008, p. 16; italics in original).

This article examines the construction of the fourth of the Sustainable Development Goals (SDG 4) within the United Nations' 2030 Agenda (UNESCO 2016a). Five years into the Agenda's runtime, now is an opportune moment to focus upon a major shift in the production of education indicators. The political work of actors involved in effecting and monitoring progress towards achieving SDG 4 requires them to come together and share knowledge and working practices, whilst at the same time preserving their respective organisation's unique "brand", their expertise and services, as well as managing their own personal values and career aspirations. This circumstance allows for a comprehensive analysis of the workings of "soft" regulation through quantification. Thus, examining these actors' work represents a unique opportunity to open a "black box" in the field of global monitoring, rather than stacking yet another one (Bhuta 2012).

This article presents a novel perspective that aims to go beyond the role of IOs in "governing by numbers" (Grek 2009). Although there have been some in-depth studies of the impact of measurement on reforms in various policy fields, little

\footnotetext{
${ }^{2}$ International organisations involved in large-scale international comparative education surveys include the United Nations Educational, Scientific and Cultural Organization (UNESCO), the Organisation for Economic Co-operation and Development (OECD) and the World Bank.

${ }^{3}$ I am alluding to soft law here, which refers to officially ratified but not legally binding instruments like international entities' resolutions and declarations (of intent) etc.
} 
attention has been paid to those early, yet crucial, venues, actors and activities that determine the nature, composition and characteristics of the transnational educational policy field. Second, this article's starting point is that numbers and (international) organisations have come to be mutually constitutive (Strathern 2000). Numbers move: this seemingly simple, yet unique quality has created a fluidity between internal organisational arrangements and external environments, as well as amongst IOs themselves. Hence, going beyond the traditional distinction made by classic organisational sociology between internal structures and external contingencies and environments, this article purports that the political work of quantification reconfigures the relationships, dependencies and structures of fields such as educational measurement in fresh and politically salient ways. How does this come about? What kinds of political work does quantification engender? How does it shape the relationships between actors and processes?

It is important to mention that this article does not claim that the production of numerical knowledge and its subsequent use for the purpose of governing is inherently problematic per se; such a claim would be simplistic and would go against widely accepted scholarly work on the role of statistics in what Anthony Giddens refers to as "the making of nations" (Giddens 1985). Rather, this article follows César Guadalupe (2017) in suggesting that criticisms of large-scale international education measurement tools need to focus on their political implications, rather than merely considering their technical aspects. Pre-determined positioning in favour or in critique of commensurability ${ }^{4}$ in global education governance is bound to miss the complexity of ever-evolving social and political phenomena, comprising a range of actors with different levels of interests, values and power in the field of global monitoring. Indeed, as Guadalupe contends,

Testing is just like any other domain of scientific enquiry. However, international assessments of learning outcomes are not necessarily, or primarily, scientific endeavours; they are political devices and ... [have] political features that, even if intertwined with technicalities, go well beyond them (Guadalupe 2017, p. 326).

Therefore, rather than understanding the role of numbers as simply the technocratic answer to governing problems, quantification offers transnational actors the potential for symbolic governance.

"Symbolic governance" denotes the potential of metrics to function as emblematic governing tools that steer not only policy problems and their solutions, but also their producers and receivers, and the relationships that bind them. In other words, the fluid, dynamic and ever-changing space of transnational governance has become dependent on the power of the political work of generating metrics not only for the primary purpose of offering technocratic and rational solutions to global challenges, but also for the secondary purpose of creating symbolic carriers of novel ways of working in the field of educational measurement. If, as this article suggests, the 21 st

\footnotetext{
${ }^{4}$ Commensurability refers to two or more things that are measurable by the same standard, which then makes them comparable.
} 
century is witnessing the rise of a global metrological field, the concept of symbolic governance allows us to analytically disentangle and understand the metrological field's structuring forces.

To provide the theoretical background, I begin this article by drawing on the relevant notions of discursive power conceptualised by French sociologist Pierre Bourdieu. This is followed by a literature review where I take a look at what scholars have to say on the role of numbers in governing societies. Next, I focus on both discursive and practical manifestations of SDG 4 in declarations, agreements, frameworks and reports etc. before addressing two alliances, the "Technical Cooperation Group" (TCG) and the "Global Alliance for Monitoring Learning" (GAML), which have (re)formed as countries join forces to tackle this education goal within the United Nations 2030 Agenda for Sustainable Development. The main part of this article features and discusses extracts from twelve interviews I conducted with key actors from all the major IOs and civil society in the context of a project funded by the European Research Council. Through a detailed analysis of both the textual evidence and these interviews, I aim to show how new discourses, practices and ways of thinking emerge. As metrics become the new lingua franca of the transnational governance of education, they constitute the necessary prerequisite for any - even remote - involvement with it. I conclude with a discussion of what this emergent picture suggests for our understanding of the symbolic governance of the transnational metrological field in education.

\section{The Bourdieusian perspective: field, symbolic capital and the making of symbolic order}

Despite the diversity of interests and positions among actors and stakeholders, metrics have become the pre-established doxa (Bourdieu 1977) ${ }^{6}$ of the unequivocal truth, monopolising solutions to complex governing problems. They have thus created, as Bourdieu would argue, a new symbolic order and therefore a "linguistic market" (Bourdieu 1977), where terms that denote quantitative monitoring and surveillance have acquired hegemonic currency and have become the primary means of communication for all actors involved. To illuminate how the notions of symbolic order and symbolic capital have been applied to the context of SDG 4, it is helpful to first turn to Bourdieu's notions of field and capital. According to Pierre Bourdieu and Loïc Wacquant (1992), the field is a social space that is autonomous and has its own rules and forms of authority. It is an arena of struggle where actors compete to maintain or change its structure and boundaries and thus advance their own position.

\footnotetext{
5 Both TCG and GAML were established in 2016. Both of these alliances are discussed in detail later in this article.

6 The ancient Greek term "doxa" is generally translated into English as "common belief" or "popular opinion". In the context of Bourdieusian theory, it refers to the misrecognition of forms of social dogma that engender a society's taken-for-granted, unquestioned truths. It contributes to the reproduction of such "truths" in social institutions, structures and relations as well as in minds and bodies, expectations and behaviour.
} 
In the Bourdieusian world, capital is an important theoretical tool, central to the notion of a field. Specifically, Bourdieu notes that "capital does not exist and function except in relation to a field" (Bourdieu and Wacquant 1992, p. 101). The idea of this kind of capital refers to any kind of resource that is useful in any given field and gives the actor the ability to gain (and be recognised as the holder of) the power which can only be obtained by competing in the field. The position of individuals or groups in the field is determined by the scope and composition of the capital they acquire and accumulate.

For Bourdieu, there are four types of capital: economic, cultural, social and symbolic (Bourdieu 1986, 2000). Symbolic capital can be understood as the result of an accumulation of the first three; it gives agents increased social status and their recognition as the sole ones who have the knowledge, ability and means to be at the forefront in a particular field (Bourdieu 2000). It is the social recognition and prestige that makes them known, famous and even loved; if they fail to achieve this status, the result could be isolation and insignificance. Achieving the required symbolic capital to be powerful in one particular field, therefore, significantly enhances their position in other fields, too. Perhaps the most important and distinctive feature of symbolic capital is that any capital can become symbolic once it is seen and recognised broadly as such (Bourdieu 1990). More crucially, the accumulation of symbolic capital enhances and legitimates the further accumulation of other capitals, irrespective of whether they are economic, social, cultural or other. As such, Bourdieu suggests that symbolic capital grants "worldmaking" power to the actors who own it, who can subsequently exercise it to shape the perceptions of the social world while giving them a taken-for-granted appearance (Swartz 2013, p. 111).

More interestingly for the purposes of this article, winning the game at the symbolic level requires "acts of performative magic" (Bourdieu, 2000, p. 243). These acts have to be performed in public. It is precisely the organisation and running of these public "events" that enable the actors who have obtained symbolic capital to call things into being; in other words, it is the combined strength of economic, epistemic, ${ }^{7}$ cultural and other capitals that allows actors to construct new realities by the very act of publicly naming and showing them. At the same time, these public events do not only create new worlds of thinking and being; they also increase the capital of the actors who perform them, giving them the appropriate "social image" to continue on their trajectory.

According to Bourdieu, the nation state holds a considerable amount of symbolic capital; it is this kind of capital that has traditionally allowed actors of the state to legitimately shape the social and economic lives of its citizens - if and when necessary, it can even use naked force to do so (Bourdieu 2014). In Bourdieu's words, the state is "the central bank of symbolic capital" (Bourdieu 2000, p. 240). Therefore, no actors who are distant from the governing machinery of the nation state can

\footnotetext{
7 Although Bourdieu himself did not use the concept of epistemic (knowledge-related) capital per se, other authors who have analysed the role of international organisations as authoritative - due to their technocratic expertise - do (Alasuutari et al. 2016). I therefore also use the term in this article as a way of emphasising the specific nature of IOs as global knowledge producers.
} 
increase or even obtain any symbolic capital to advance their position. Nevertheless, Bourdieu was less clear on what forms symbolic capital takes at the level of the transnational; of course, the transnational is still made up primarily by national actors and national politics. As this article clearly demonstrates, though, there are two other features of transnational politics, namely international organisations and metrics, whose roles need further exploration if one is to interpret the rise of a transnational governing field.

Thus, drawing on Bourdieu, transnational governance appears as a field of actors who are constantly engaged in negotiating and pushing their own agendas forward; according to him (Bourdieu 1993), what gives the notion of the field meaning is the logic of positionality. In other words, the positions occupied by the different agents in the field, their advances and withdrawals, relate to their efforts towards attaining distinction within this field as an expression of their professional, educational or other interests. Meanwhile, the structure of the field is neither static, nor does it change in any systematic way. On the contrary, it is endlessly reformulated, according to the agents' struggles for recognition and improvement of their situation. Agents use the force of their economic, social, cultural, or - in the case under examination in this article, symbolic capital, to raise their game and advance their front. It is the relational nature of these advances that gives the field its explanatory significance (Grek 2016, with reference to Bourdieu 1993).

Emanating from physics, the notion of a field has been used in the social sciences in order to broadly refer to actors' relational topographies. Nevertheless, it is often reduced to merely looking at specific geographical and relational spaces. Yet, as Marie-Laure Djelic and Kerstin Sahlin-Andersson suggest, such a conceptualisation of fields misses a vital ingredient of the way in which they operate; that is, an understanding of the field as a field of power. Based on Bourdieu's theory, Djelic and Sahlin-Andersson developed the idea of fields as

complex combinations of spatial and relational topographies with powerful structuring forces in the form of cultural frames or patterns of meaning (Djelic and Sahlin-Andersson 2006, p. 27).

This idea is well-suited to the purposes of this article, and demonstrates the necessity of a holistic examination of the interplay of IOs. Rather than looking at transnational governance only as a field of numbers or only as a field of actors, it is imperative to consider it as both; that is, examine it through the concept of rise of the global metrological field.

This article argues that IOs, and especially those that participate in the measurement of educational levels of proficiency which are relevant to SDG 4, are continuously engaged in the business of translating their knowledge capital into symbolic capital. In other words, although technical, highly complex statistical expertise is essential, it cannot accrue benefits unless it is recognised as such; it therefore needs to be transformed into symbolic capital. It is precisely their epistemic capital translated into symbolic capital that bestows on IOs the "authority to impose the legitimate knowledge of the sense of the social world, its present meaning and the direction in which it is going and should go" (Bourdieu 2000, p. 185, emphasis in original). Before I move on to the empirical evidencing of the article's argument, the 
next section explores precisely how the work of numbers allows IOs to achieve these "world-making" powers.

\section{All that counts? Interplay, quantification and the co-construction of global governing vistas}

Moving on from this brief overview of the relevant Bourdieusian theoretical background, it is also important to give a short account of what scholarship on the role of numbers in governing societies has so far suggested. This is crucial for the purposes of this article, since numbers represent the connective tissue that gels IOs, individual actors, processes, symbols and relationships in the making of the transnational metrological field in education.

Although research on the interdependencies of IOs is scarce, scholarship on the role of numbers in governing societies has been abundant and has attracted multiple fields of study, including sociology, history, political science, geography, anthropology, philosophy, science and technology studies (STS) and others. Prominent authors have written lucidly about the role of numbers in the making of modern states and about the governing role of measurement regimes in various areas of public policy and social life (Alonso and Starr 1987; Hacking 1990, 2007; Porter 1995; Power 1997; Desrosiéres 1998; Rose 1999; Espeland and Stevens 2008). Similarly, "anthropologies" of numbers ${ }^{8}$ suggest that "our lives are increasingly governed by - and through - numbers, indicators, algorithms and audits and the ever-present concerns with the management of risk" (Shore and Wright 2015, p. 23; see also influential work by Sally Engle Merry 2011; Sauder and Espeland 2009; and Marilyn Strathern 2000). Further, important insights and perspectives on indicators in particular come from STS (Bowker and Star 1999; Lampland and Star 2009; Latour 1987; Saetnan et al. 2011), including actor network theory ${ }^{9}$ (Latour 2005). Finally, there is a small but growing body of studies relating to specific uses of indicators and quantification in transnational governance contexts (for example, Bogdandy et al. 2008; Palan 2006; Martens 2007; Fougner 2008; Bhuta 2012).

So what are the properties of numbers that would suggest such a central role in the production of transnational governance? By contrasting numbers with language, Hans Krause Hansen and Tony Porter (2012) suggest that, although it took scholars a long time to recognise the constitutive nature of discourse, we are now well aware of the role of language in shaping reality. However, they suggest that numbers are characterised by additional qualities that make their influence much more pervasive than words; these elements are: order; mobility; stability; combinability; and

\footnotetext{
8 The somewhat unusual transdisciplinary combination of anthropology (the study of human cultures) with numbers (the realm of mathematics) was first made by Thomas Crump in his book entitled, The anthropology of numbers (Crump 1990). I use the plural here, anthropologies, to refer to the growing and diverse anthropological accounts of the making of numbers.

9 Conceptualised by French philosopher, anthropologist and sociologist Bruno Latour (2005), actor-network theory (ANT) is a sub-category of social theory. ANT is quite complex, but in a nutshell, it is concerned with the interaction between networks of human (social) and nonhuman (technical) actors.
} 
precision. By using the example of the barcode they lucidly illustrate "how numerical operations at different levels powerfully contribute to the ordering of the transnational activities of states, businesses and people" (Hansen and Porter 2012, p. 410). They suggest the need to focus not only on the nominal qualities of the numbers themselves, but also on what Ian Hacking lists as "the people classified, the experts who classify, study and help them, the institutions within which the experts and their subjects interact, and through which authorities control" (Hacking 2007, p. 295).

It is precisely the symbolic function of number-making that this article focuses on. In their movement, data go through successive reductions of complexity until they reach a sufficiently simplified state that can travel back "from the field to the laboratory, from a distant land to the map-maker's table" (Hansen and Porter 2012, p. 412). While IOs constitute such "centres of calculation", according to Merry this does not, however, suggest that IOs are significant only in terms of their knowledge production capacities. By specifically examining the role of indicators in transnational governance, Merry elucidates their governance effects (Merry 2011), which leads to the premise that if we consider IOs to be central to the production of knowledge, we can infer that their operation as knowledge gatherers, controllers and distributors must have crucial governing impact. These effects empower IOs and position them in a complex and ever-evolving power game for influence and resources. It is precisely this power game and its rules that this article aims to cast light upon through an examination of the interplay and interconnectedness of IOs' data and methodology apparatuses.

What, then, is Bourdieu's relevance to the analysis of the governing effects of quantification? The role of numbers as a symbolic order, as will be further exemplified in this article, is precisely an attempt to disentangle the constitutive parts of this governing work. Harnessing the concept of symbolic governance to this task of disentanglement helps to better understand the role of numbers as the sine qua non (essential condition) for the transnational governing of public policy arenas. At least in the field of education, quantification and transnational governance are inextricably interlinked; it is a doxic (commonly taken-for-granted) relationship that "goes without saying because it comes without saying" (Bourdieu 1977, p. 167). In addition, symbolic governance can cast light on the "dramaturgy" of the rituals of number-making: these are both the public and the backstage work of the meetings; the casting of key and peripheral actors; the organisation of key physical and online "events"; the rhetoric of speeches and executive media spin; the affective (emotionally influenced) data visualisations; as well as the crucial dimension of political time, capitalised either as urgency and crisis or in the form of "future-proofing". Numerical work is crucial here in order to glue these inter-cultural, asymmetrical actors together in the quest for deep change. Through a series of "key" formal and smaller informal events, the formation of indicator groupings, the regular publication of reports and interactive data visualisations, a governing infrastructure is built. The symbolic power of numbers as doxa and as a vehicle creates "living institutions" that are forever unfolding, dynamic and multidimensional. Perhaps this is precisely the secret of their durability and attraction; informality, multiplicity, dynamism and flexibility - all these are characteristics which are quite uncommon in much more traditional, stable and structured government processes. 
Empirically, education's emergence as a metrological field has arisen from the way in which education policy, both in the Global South and the Global North, has increasingly been dependent on the measurement of its performance for the improvement of human capital (Ydesen and Grek 2019). In addition, education can be a productive vantage point, since assessment and quantification of performance have a very long history in the field. It is a key element in the newly emergent wellbeing and "better life" strategies that gained prevalence in the post-financial crisis statistical governing project (Stiglitz et al. 2009). Education is to some extent congruent with the efforts to use "softer" data sets for "calculating the social" (Higgins and Larner 2010). Last but not least, it is one of those policy areas in which large IOs like UNESCO, the OECD, the European Commission and the World Bank have accumulated large amounts of data and expertise since the middle of the 20th century.

\section{Methodology}

In methodological terms, this article is largely informed by a critical discourse analysis of a large number of SDG 4-related reports and documentation materials, as well as twelve interviews with key actors in the production of statistical data for Education 2030 (SDG 4).

Evaluating indicator-related texts, such as declarations, agreements, reports, minutes of meetings and conference presentations, I use critical discourse analysis (CDA) (Chouliaraki and Fairclough 1999) in order to establish key topics discussed in these sources. My aim in using CDA is to go deeper into an investigation of the ways in which language contributes to the framing of new issues and the construction of new worldviews.

The evaluation of the documents is complemented by the twelve in-depth interviews to elaborate on nuances and explain aspects of the actors' work and their experiences of meetings and events which are not easily depicted in text analysis.

\section{SDG 4 through the discursive lens}

The purpose of this section is twofold: first, it aims to offer a broad overview of the key developments and reports in the shaping of SDG 4. Second, and perhaps more significantly, it aims to show how through a series of major events and the publication of - seemingly - pivotal texts, such "declarations", large global "agreements" and "frameworks for action", the work of numbers is enveloped with a very strong discourse of development, equality, democracy, universality and morality. Apart from this discourse of inclusivity, emergency and the need for radical change, most of these texts also create fairly tight and complicated matrices of different goals, standards, indicators and benchmarks, thus offering a degree of transparency, yet simultaneously - due to their unreadability - taking it away. 
Thus, the purpose of this article is to explain how the construction of the Bourdieusian "doxa" works. Whilst on the one hand, numbers allow a certain sense of mystification through the construction of long lists of indicators and sub-indicators (a world where "insiders" operate with communicating via codes such as " 4.1 ", "4.2", "4.1.1", etc.), ${ }^{10}$ on the other, this is enveloped with the grand language of universality, morality, a sense of urgency and solidarity. This is Bourdieusian "doxa": the muddling of the technical and the political, and the transformation of this new common language into the singular, universally accepted method of communication.

The Education 2030 Agenda relates to the collaborative development of the knowledge and policies necessary to achieve SDG 4, which vows

to ensure inclusive and equitable quality education and promote lifelong learn-

ing opportunities for all (UN 2015).

The Education 2030 Agenda brings together a range of international organisations, namely UNESCO, along with the United Nations Development Programme (UNDP) and the United Nations Children's Fund (UNICEF); the World Bank Group; the OECD; the International Labour Organization (ILO) and a few smaller ones. These organisations do not operate in this context out of their own accord; they are the "custodian agencies" which are mandated, under the SDG "country ownership" governing mantra, to implement Member States' decisions (Fukuda-Parr and McNeil 2019; Dodds et al. 2017). This is a very important shift achieved with the SDGs as they replace their predecessors, the Millennium Development Goals (MDGs) (Fukuda-Parr 2016), and therefore the agency and power of the participating countries cannot be underestimated. However, an analysis of countries' participation in the Education 2030 Agenda (SDG 4) is beyond the scope of this article, which looks specifically at the role of IOs in the process. The SDGs are therefore not a standalone performance measurement exercise, but are rather organised under the rubric of a much larger monitoring programme with its own internal logic, structure and hierarchies. SDG 4 thus represents a significant case of transnational governance of education, and more specifically of the infrastructures and interdependencies of IOs in the construction of education data within all 17 SDGs.

\section{The Incheon Declaration}

One of the key documents that sets out the Education 2030 Agenda in detail is the Incheon Declaration and Framework for Action (UNESCO 2016a)., signed at the World Education Forum 2015 held in Incheon, Republic of Korea, from 19 to 22 May 2015. The Declaration "sets out a new vision for education for the next fifteen years" (ibid., p. 5) and thus is considered a key programmatic document in relation not only to what Education 2030 entails, but also in outlining the proposed means to achieve it. Although the Declaration refers to previous initiatives such as "the

\footnotetext{
${ }^{10}$ In the context of SDG 4, these mysterious figures refer to this goal's targets (e.g. 4.1, 4.2) and indicators (e.g. 4.1.1); see UN (2015).
} 
worldwide movement for Education for All initiated in Jomtien in 1990 and reiterated in Dakar in 2000", it nevertheless suggests that, despite these efforts, there are great concerns that the education community is still very far from reaching these objectives (ibid., p. 6)

The Declaration refers to the Muscat Agreement (UNESCO 2014), which was developed at the end of the agenda preceding Education 2030 at the Global Education for all (EFA) meeting in 2014 and fed into the education targets proposed by the Open Working Group on Sustainable Development Goals (SDGs) for the new agenda. The Declaration also mentions some of the education-related goals that had appeared in the Millennium Development Goals (MDGs) ${ }^{11}$ and suggests that "Education 2030" is a continuation of those. According to the Declaration, SDG 4 is

transformative and universal ... inspired by a humanistic vision of education and development based on human rights and dignity; social justice; inclusion; protection; cultural, linguistic and ethnic diversity; and shared responsibility and accountability. We reaffirm that education is a public good, a fundamental human right and a basis for guaranteeing the realization of other rights. It is essential for peace, tolerance, human fulfilment and sustainable development. We recognize education as key to achieving full employment and poverty eradication (UNESCO 2016a, p. 7).

Thus, the Declaration represents a clean break from connecting education exclusively to economic considerations and reiterates the moral obligation to offer it to all, while at the same time connecting it to many other policy areas and social issues, such as sustainable development, employment, social inequality etc. For example, there are explicit mentions of the agenda's wider policy focus, not only on basic education for all, but also on the relevance of learning outcomes both for the world of work and for citizenship. The discourse developed in the document therefore not only has just a moral undertone; risk and the ethics around the need to find solutions are, in fact, centre-stage in the Education 2030 Agenda.

UNESCO as the lead organisation in promoting and monitoring progress towards achieving SDG 4 is mandated to act as a knowledge and policy hub. According to the Declaration, it will be

undertaking advocacy to sustain political commitment; facilitating policy dialogue, knowledge sharing and standard setting; monitoring progress towards the education targets; convening global, regional and national stakeholders to guide the implementation of the agenda; and functioning as a focal point for education within the overall SDG coordination architecture (UNESCO 2016a, p. 10).

Although efforts towards achieving SDG 4 have led to the construction of a complex structure of quantitative measures, the operation as a whole has a clear set of broader

\footnotetext{
11 The 2030 Agenda (2015-2030) with its 17 SDGs was preceded by the Education for All agenda (1990-2015) with its 8 Millennium Development Goals (MDGs). For more information on the MDGs, visit https://www.un.org/millenniumgoals/ [accessed 7 June 2020].
} 
aims, too. Within the single overarching goal of SDG 4, the Framework for Action (UNESCO 2016a, pp. 15-84) highlights 4 main targets (all of which come with indicative strategies to achieve them; ibid., pp. 29-30). These 4 targets (equity and inclusion; gender equality; quality; and lifelong learning), are informed by 3 principles (fundamental human right; public good; and gender equality; ibid., pp. 28), 5 strategic approaches (strengthening policies, plans, legislation and systems; emphasising equity, inclusion and gender equality; focusing on quality and learning; promoting lifelong learning; and addressing education in emergency situations; ibid., pp. 31-34), 4 levels of indicators (global [11]; thematic [43]; regional; and national; ibid., p. 56, pp. 72-81). SDG 4 also comes with a specific set of guidelines concerning "governance, accountability and partnerships" (ibid., p. 57), which stress that the co-conveners (UNESCO, UNDP, UNFPA [the United Nations Population Fund], UNHCR [the United Nations Refugee Agency], UNICEF, UN Women, the World Bank and ILO, ibid., p. 61) will need to work with regional and intergovernmental organisations, under the direction of the SDG-Education 2030 Steering Committee. "Global monitoring" and review will be continuous and will be delivered by the UNESCO Institute of Statistics (UIS), which will facilitate "the sharing of best practices with a view to strengthening country data systems, particularly for African countries, least developed countries, landlocked developing countries, small island developing states and middle income countries" (ibid., p. 64).

Finally, discursively at least, other interesting features of the Framework for Action are the repeated emphasis on the need for capacity building in relation to statistical expertise, as well as the need for "sustained, innovative and well-targeted financing and efficient implementation arrangements" (ibid., p. 66). In fact, a "guide" prepared by UNESCO's Section of Partnerships, Cooperation and Research, Division for Education 2030 Support and Coordination. Entitled Unpacking Sustainable Development Goal 4 Education 2030 (UNESCO 2016b) states that SDG 4 targets and policy priorities are explicitly promoted as needing to become part of existing national education policies, plans and processes. The guide strongly advises that efforts to realise SDG 4 commitments should not result in parallel or separate plans and processes.

SDG 4 policy commitments do not exist outside of existing national policies, planning, management and monitoring processes and mechanisms. Rather, existing country-led systems, processes and mechanisms should be supported or strengthened to ensure better alignment/adaptation with global commitments (ibid., p. 19).

To conclude, it is evident that the Education 2030 Agenda is not exclusively a performance monitoring project, limited to requiring participating countries to regularly provide progress data towards the set goals. Rather more ambitiously, SDG 4 is presented in these documents as no less than a governing programme with a heart and soul. It aims to be seen as necessary, ethical, participatory and local; in fact,

\footnotetext{
12 The UNESCO-led SDG-Education 2030 Steering Committee is the global multi-stakeholder consultation and convening mechanism for education in the 2030 Agenda (UNESCO 2019).
} 
there is little emphasis on numbers in the reports discussed above. In this sense, these findings concur with previous research that sees the SDGs as being discursively constructed as "transformative", including "more elements of a human development and capability approach ... They expand in scope ..., reach ... and engagement of different stakeholders" (Fisher and Fukuda-Parr 2019, p. 376).

Discursively, the production of statistical data is absent in the documents discussed. Yet, this is precisely what the notion of numbers as symbolic order is about: the construction of an "infrastructure of measurement" that involves the creation of "a knowledge system about ways of converting ideas about social life into numbers" (Merry 2019). The new orthodoxy of numbers does not need discussion or description; it is a given and has become a routinised "way of doing things"; in that sense, it is merely a dimension of the "metrics infrastructure". This is precisely why the "discursive labour" can then focus on constructing a series of new symbolic gestures in terms of collaboration, equality of participation, and alertness to the risk of falling behind if the agenda is not fully integrated in national education policymaking. Thus, the notion of symbolic governance refers to the political work of the staging of all those necessary, yet often informal, public and backstage rituals, rhetoric, symbols and images required for transforming a deeply pragmatic and technocratic endeavour into a compelling "story" for the audiences within and beyond its immediate cast and confines.

\section{Fields and actors: The "Technical Cooperation Group on the Indicators for SDG 4" and the "Global Alliance for Monitoring Learning"}

Similar to the workings of discourse in the construction of a common language in transnational education governance, the practices of actors involved in the shaping of SDG 4 can also be examined through the notion of symbolic capital, and what the accumulation of such capital suggests for the actors' position and movement within the metrological field. This section turns the spotlight onto these key people, who, although occupying technical positions, have also been given a strong mandate towards achieving consensus amongst the wide diversity of participants in what is often referred to as the "indicator debate". Thus, this section focuses on the struggles and tensions but also on the opportunities of transforming actors' epistemic, highly technical knowledge capital into symbolic capital - an aspect which seems useful in further establishing the dominance of metrics and of those who construct them. Not only does the indicator debate promote the monitoring agenda and co-opt a wide range of actors; it crucially also further legitimises the actors' key position by affording them even more symbolic capital in the process.

In order to demonstrate the mechanisms of the transformation of epistemic capital into symbolic capital, it is useful to discuss the work of two key indicator groupings, namely the Technical Cooperation Group (TCG); and the Global Alliance for Monitoring Learning (GAML). While this section derives sme data from the extensive online documentation of their regular meetings, it is primarily based on actors' 
own voices as participants of these meetings and as key active participants in these groups.

Although 2015, the year the 2030 Agenda for Sustainable Development and its SDGs were launched, seemed like the dawn of a new era for the global education community, it left a number of issues open - among them the so-called indicator debate. As mentioned in the previous section, the Incheon Declaration and the Framework for Action established four levels of indicators (global, thematic, regional and national). The first level included up to 11 global indicators, negotiated in a series of meetings of the Inter-Agency Expert Group on SDG Indicators (IAEG-SDGs). ${ }^{13}$ In light of the unequal development of these indicators, ${ }^{14}$ and often the unavailability of data and lack of coverage on a global scale, IEAG-SDGs implemented a 3-tier classification tool, ${ }^{15}$ which categorised indicators depending on their robustness according to internationally established methodologies and standards and the regularity of data production at country level. Importantly, IAEG-SDGs also identified a number of custodian agencies they deemed responsible for the development and refinement of such indicators. In the case of education (SDG 4), the UNESCO Institute of Statistics (UIS) became the responsible entity for 9 out of 11 indicators, and was tasked to share the responsibility for the other 2 with UNICEF and the OECD. Given the initial classification of a number of metrics as tier 2 and tier 3 indicators (e.g. indicators for which data are not regularly produced by countries or for which measurement standards are not yet available), their refinement and production rapidly become a priority for UIS, who, as discussed below, perceived its organisational legitimacy and reputation as being closely tied to achieving both technical solutions as well as the consensus of the participant actors about the pertinence and suitability of the indicators under consideration.

Given the complexity of the endeavour, but also in order to guarantee the participation of a wide range of stakeholders, two ad hoc mechanisms/working platforms were created with a view to advancing the development and production of SDG 4 global and thematic indicators. One was the "Technical Cooperation Group on the Indicators for SDG 4" (TCG) and the other was the "Global Alliance to Monitor Learning" (GAML).

The former was established in 2016, being conceived as a space for discussion as well as a technical platform to support UIS in the implementation of the thematic indicator framework. TCG is composed of regionally representative UNESCO

\footnotetext{
13 The Inter-Agency Expert Group on SDG Indicators (IAEG-SDGs) was created on 6 March 2015 by the United Nations Statistical Commission at its forty-sixth session. For more information, visit https:// unstats.un.org/sdgs/iaeg-sdgs/[accessed 9 June 2020].

14 The development of indicators is unequal in terms of their being at very different levels of development, ranging from concrete ones (supported with data) to those described as tier 3 indicators (see next footnote), i.e. lacking an established data infrastructure to measure them..

15 An indicator in tier 1 is defined as being conceptually clear, having an internationally established methodology and available standards, with data being regularly produced by at least 50 per cent of countries in every region where the indicator is relevant. An indicator in tier 2 is conceptually clear, has an internationally established methodology and available standards, but data for this indicator are not regularly produced by countries. An indicator placed in tier 3 is one for which no internationally established methodology or standards are yet available, but are being (or will be) developed or tested (UN 2020).
} 
Member States, as well as representatives of different IOs (UNESCO, UNICEF, OECD and the World Bank), civil society organisations and the co-chair of the Education 2030 Steering Committee.

GAML was also created in 2016, being originally defined as an "umbrella initiative to monitor and track progress towards all learning-related Education 2030 targets" (UIS 2016, p. 49), and tasked with the development of tools, methodologies and shared standards to measure learning outcomes in the context of SDG 4. Its membership is open to any individual or organisation willing to contribute to the work of GAML, and includes IOs, civil society organisations, a variety of technical partners and assessment organisations, and representatives of United Nations (UN) Member States. Similar to TCG, GAML operates by definition in an open and participatory manner, with decisions being made through consensus.

Importantly, these platforms did not emerge in a vacuum. On the contrary, both of them were born out of already existing initiatives launched during the run-up towards the approval of the Education 2030 Agenda. More specifically, TCG represents a continuation of the Technical Advisory Group (TAG) established in 2014, chaired by UNESCO and including experts from a range of education-related multilateral agencies. GAML, in turn, was a successor of the Learning Metrics Task Force (LMTF), launched in 2012 and envisaged as a multi-stakeholder partnership co-convened by the Center for Universal Education (CUE) at the Brookings Institution and UIS. For both TCG and GAML, there is extensive online documentation of their regular meetings, but they only really come alive in the voices of individual participants of these meetings.

The research I present in this article is part of a project funded by the European Research Council (ERC) under the European Union's Horizon 2020 research and innovation programme. The project, entitled "International Organisations and the Rise of a Global Metrological Field" (METRO), aims to "cast light on metrics and transnational governance". ${ }^{16}$ Working on a case study of "Education 2030 (SDG 4)" within the context of this project, I have so far conducted twelve interviews ${ }^{17}$ with key actors from all the major IOs and civil society. Below, I present some excerpts from their responses.

According to two interviewees,

The [technical advisory] group that led the developments, that gave us the current indicators for SDG 4 was a precursor of TCG and GAML. And it was essentially the same composition ... that group basically just renamed itself as the TCG. They worked on the indicators that were then adopted. (UIS 1) ${ }^{18}$

The Learning Metrics Taskforce was another space where conversations were held and where I think most of the big actors in the global education policy space were somehow represented. I mean if you look at institutions involved

\footnotetext{
16 For more information about the METRO project, visit its dedicated website at http://www.metro-proje ct.eu/.

17 My research is ongoing, and I will be conducting more interviews in the context of this project.

18 To protect interviewees' identities, I refer to them here merely giving an indication of their background (e.g. UIS, World Bank, OECD, UNESCO or Civil Society), with numbers merely serving to distinguish between multiple respondents from the same institution.
} 
... so I think that also contributed to a consensus building that's become really hard to resist. (Civil society 1 )

Nevertheless, despite a certain path dependency, the (re)formation of both TCG and GAML entailed a procedural shift vis-à-vis their own precursors. Both initiatives were explicitly set up in the understanding that they would be subject to a transparency mandate, and were expected to operate in a democratic, equitable and inclusive manner. In this sense, both platforms or spaces are subject to a dual form of accountability - they are held responsible for the success of their technical work, but also judged in terms of the quality and inclusive character of their deliberations. To put it differently, both spaces are characterised by an inbuilt tension between the technical and the political accountability of the whole endeavour. An analysis of the work of the two indicator groups is therefore a productive space which serves as the canvas for mapping the struggles of the actors' positionings and efforts for recognition and distinction in the field. This tension is primarily evidenced through the centrifugal forces of technocracy versus the perceived need for SDG 4's inclusivity. As a number of my interviewees suggested, this has created a set of quality assurance problems that, although extant before, were never quite as prominent as in the case of the Education 2030 Agenda (SDG 4):

I think the way that UIS and GAML are trying to manage this is, say, if countries want to submit their national assessment data, that's fine, no problem. But I think we're trying to manage by then saying, but we are going to put your data through a quality control process. And that's going to tell us technically how strong the data are. It doesn't mean we're not going to publish it, but the data may be published with an asterisk or footnote or in a slightly different way to signal to the viewer of the data that this is not exactly the same as say a TIMSS score or a PIRLS score ${ }^{19} \ldots$ it's let's get them in the door, let's just get it started, get people used to the habit of data on learning, then gradually raise the bar. (World Bank 1)

However, not all IOs share this tendency of prioritising inclusion over data robustness:

There is no clear-cut answer to this, I think it's a very difficult dilemma. But it also reveals a very different approach between UNESCO and OECD on how to respond to this. And we have encountered this not just in the outcomes metric but also in a way with general statistics. The UNESCO philosophy being we need to be open, we need to accept the constraints and at the end of the day it's better to have something than to have nothing. At the

\footnotetext{
19 The acronym TIMSS stands for Trends in International Mathematics and Science Study. PIRLS stands for Progress in International Reading Literacy Study. TIMSS and PIRLS are international assessments that monitor trends in student achievement in mathematics, science and reading. Both are conducted by the International Association for the Evaluation of Educational Achievement (IEA), an international cooperative of national research institutions, governmental research agencies, scholars and analysts. For more information, visit https://www.iea.nl/studies/iea/[accessed 7 May 2020].
} 
OECD I have taken a very different approach to this. For me, the most precious currency is trust. If I know that policymakers do not trust the data or don't trust them to be comparable, the whole thing is of very little value to me, because I want these things to be actually having an impact on this. So basically UNESCO and OECD use the same data source on the administrative side at least. With UNESCO the tables are full; for the OECD we have half of the cells filled with an M, which means actually these data aren't good enough. And the interesting thing though is that this has dramatically changed over time. Dramatically in the sense that most of these gaps are now filled and countries have tried harder to build more comparable metrics, so we have never lowered the standards, but try to help countries meet those standards. We even have another category that is more controversial. What often happens, both at UNESCO and the OECD, is that countries may not want to reveal certain elements and then we have no data either. And in the case of the OECD I have made this explicit too, there is another category that says "data withdrawn on the request of the national authorities". So it's very clear you choose not to be part of this. You can do that, but it's transparent. And actually again at the beginning we had lots of occasions like this and now it's almost zero, because then suddenly countries need to think about these kind of questions. (OECD 1)

The latter quotation is exceptionally telling in terms of the work that numbers do in the construction of coalitions of actors, even when the data are not there at all. This is precisely the symbolic function of numbers; even in their absence, they create the conditions for consensus and coalition-building. On the one hand, UNESCO appears to be using statistical data as the means to mobilise an ever greater number of countries to participate in the global measurement operation. UNESCO'S primary "currency" is inclusion and equal participation of all actors in the policy process; it uses numbers as a symbolic emblem of the belief of the organisation in more democratic and transparent processes of transnational education policymaking and monitoring. The OECD and the World Bank, on the other hand, still appear to be immovable from their core technocratic tenet of "trust in numbers"; they use peer pressure to encourage countries to conform and participate. The symbolic use of the "M" to denote missing data is not an empty cell; it symbolises in many ways the peer pressure and governing function that numbers have.

However, I do not wish to present these organisations as being in any way monolithic. The majority of actors I interviewed, even ones from the same organisation, often gave divergent views of their organisation's approach to data robustness and validity. However, it is precisely the contentious issue of the conflict between the technical and the political accountability of the monitoring tool which has been the breeding ground for the emergence of what I refer to in this article as the "metrological field" that governs transnational education. This field is inhabited by individual actors who assume different positions, sometimes following the culture of the organisation that employs them, but also - indeed often - not. These actors use their accumulated epistemic, economic, social or other capitals in order to transform them into symbolic capital that determines their visibility, authority and legitimation in 
the field. More often than not, my interviewees cited their own career trajectories, values, frustrations or aspirations as the reasons which led them to take the position they had assumed; these positions are not permanent and solid. They often change in the face of developments in the "field", i.e. the positionality, advancement and withdrawal of other actors involved in it. This conditions not only how they act, but also how they present themselves; style and substance can be of equal weight here.

\section{Staging the meeting: symbolic rituals and the making of numbers}

Observing the process and practice of these groups' gatherings is perhaps the most telling material evidence of how meetings contribute to the structuration of the broader metrological field. Anthropologist Clifford Geertz's idea of the "poetics of power" (Geertz 1980) is useful for unravelling the thick layer of dramaturgy coating this apparently technocratic regime. Several of my interviewees suggested that most meetings are performative events, which follow a certain ritual, allowing enough free space to conclude with some loose decisions that determine the agenda for the follow-up meeting. The predominance of actors suggests that there is a clear-cut distinction of participants from the Global North, whose presence and contributions dominate the meetings, whilst representatives from countries of the Global South most of the time have a very passive presence, if any at all. This of course does not negate the agency and power of participants from the Global South, especially in relation to exploiting their own perceived weak positioning in order to accomplish specific goals. Thus, the space of the meetings becomes the visual manifestation of those who carry symbolic capital (and exercise authority) and those who do not, and whose lack of symbolic capital ironically enough also becomes a source of strategic positioning, since their agreement to the proposed agenda is required for the process to move on.

Further, the ambiguity and informality of the process, despite being an issue for some in the room, becomes a valuable, malleable tool in ensuring participation, while at the same time also pushing on with a specific, pre-determined agenda:

This was a big argument in the [removed for anonymity purposes] meeting two years ago. Because initially the [removed for anonymity purposes] ended up being a meeting of all the different actors in the assessment field, and they were kind of fighting among each other trying to frame their own assessment as the best for any SDG monitoring efforts. And this of course means that you have quite a lot of conflict of interest in the room. So one of the things that we as [removed for anonymity purposes] tried to say quite early on was that for this to be a well-functioning body that can actually do some work we would need to be quite clear on how decisions are made. And are we working on consensus basis, how do we deal with the fact that so many people have a conflict of interest; who will draw conclusions; if there's voting, with what numbers would something have to be supported for it to be carried? And this was a frustration that grew as every session basically just ended with a broad sweep- 
ing, this was a very good discussion, thanks guys. And it was never really clear what anything would result in. (Civil society 2)

Interestingly however, frustration and discord about the lack of transparency are not sufficient reasons to disassociate oneself from these alliances; being present at the discussions even when one is at the receiving end is still considered more valuable than not participating in such meetings. This kind of peer pressure, the discourse of crisis and the need for active involvement despite failings and malfunctions, trumps any hesitations about the process itself. In fact, as we see below, the process is informal enough to invite the complainant to try and sort out their own complaint:

[removed for anonymity purposes] then proposed that what if we had a strategic coordination committee that could approve the agendas in advance and that could try to ensure that this works well. And then [removed for anonymity purposes] was of course invited to be part of this, which was a clever move because we had probably been, if not the, at least one of the most critical voices in the room. So we had a dilemma and ended up actually agreeing to be part of this committee ... I think what we struggle with is the fact that we know that just by being in the room, we are giving an indirect blessing of what the [removed for anonymity purposes] is doing. And at the same time, if we are not in the room, then we have no access to the conversations. We don't know what's going on. So we still feel like somehow we have to be in the room (Civil society 1).

Chairing the meetings, although seemingly simply an administrative task, can also play an important role not only in how the meeting is run, but also in the conclusions that are drawn. Some of my interviewees suggested that the choice of chairpersons is strategic and aims to avoid (or prompt) specific actions, or the divergence of the problem to where the IOs want it to be:

Then the chair of the session will basically just wrap up, often without any reference to how things will move on. And this is enabled by the fact that [removed for anonymity purposes] is very seldom chairing the sessions herself, but she asks other people to chair. So you would have for instance the representative of the Australian Department for Trade and whatever it's called, foreign affairs and trade, I guess, chair a session. And then he will not in a way be expected to do the wrap-up in terms of follow-up, but he's really just brought in as the one who's facilitating the session. And then [removed for anonymity purposes] is doing a concluding statement of some sort, where she often has a PowerPoint and she would outline the next steps. But it's always completely unclear how the critical input from the group is really going to feed in or shape things (Civil society 4)

Finally, as suggested earlier, the SDGs have prioritised consensus-making and the "democratisation" of data as key in any forward-going process. Given the power asymmetries and the often informal management of the process, such efforts are frequently interpreted as a symbolic gesture that might even threaten the doxa of "trust 
in numbers" - they are, in a sense then, a "hetero-doxy", a necessary deviation from accepted standards to sustain the ambivalence and multiplicity of the field.

It is precisely this conflict between methodological robustness and democratic participation that seems to set the SDG 4 wheels in motion. Although IOs seem to have the epistemic capital to drive the process, the need for participant countries to agree and approve suggests that other forms of capital are key, too. This leverage that participant nations and other civil society organisations have can be seen as problematic at times:

These are the professional standards of the measurement community. These are the instruments that are going to help you align your assessment with what good practice is, we're recommending you use it. But it feels like we've gone into a whole second phase of, and now we're going to get all the countries together, and we're going to get everyone's buy-in. And it keeps going back to this theme of democracy and voice. Is there such a thing as too much democracy, too much consultation? At what stage do you say we just have to run with this, this is what it is? (World Bank 1)

According to most critics of the Bourdieusian oeuvre, the idea of symbolic order and the accumulation of symbolic capital suffer from the fact that - in his view of the world - it does not allow change to happen. How do those who lack symbolic capital change their positions? The case of Global South participants' positioning in the SDG 4 TCG meetings shows that it is not just one form of capital that matters, but a combination of them. Nevertheless, for those who take a closer look, Bourdieu's theory allows some space within the interlocking whole that ensures the reproduction of existing hierarchies and social orders. In the final chapter of his Pascalian meditations, Bourdieu returns to symbolic struggle, and in this iteration he introduces an entirely new dimension: the symbolic order constitutes a space of relative autonomy with a margin of freedom for redefining the world and opening up new possibilities:

But there is also the relative autonomy of the symbolic order, which, in all circumstance and especially in periods in which expectations and chances fall out of line, can leave a margin of freedom for political action aimed at reopening the space of possibles. Symbolic power, which can manipulate hopes and expectations, especially through a more or less inspired and uplifting performative evocation of the future - prophecy, forecast or prediction - can introduce a degree of play into the correspondence between expectations and chances and open up a space of freedom through the more or less voluntarist positioning of more or less improbable possibles - utopia, project, programme or plan - which the pure logic of probabilities would lead one to regard as practically excluded (Bourdieu 2000, p. 234; emphases added).

To conclude, one of the greatest difficulties of analysing the emergence of the transnational metrological field is its complexity, dynamism and multiplicity. Although quantification has dominated global governance as the new unequivocal doxa of planning the future, it is precisely those same numbers that allow new utopias and 
dreams to emerge as an alternative heterodoxy for the creation of a better world - or, as Bourdieu terms it above, the "improbable possibles". As noted earlier, this article does not see quantification as evil, not even as a necessary one. Rather, through a discussion of the discourses and the political work of actors involved in processes of quantification, my aim here is to demonstrate how numbers can create the necessary infrastructures to facilitate new ways of perceiving, constructing and hence governing the world. According to one of my interviewees,

You look at the SDG indicator framework, to be honest, it really does make no sense from a statistical point of view ... But it's not the data, because you can have the data but you can still miss the goal ... [SDG 4] will not be achieved probably. [Our work] is awareness raising I would say, then of course the methodological development, and really assisting Member States because we serve them as agencies. I love numbers ... For me it's the joy of looking at some - let's take a massive amount of data - and getting a message out of it, right? Look at something, and then you find out what can this teach us. And then also beyond that of course is the mission of the UN, which I strongly believe in. It's to improve everyone's lives, and to help Member States, and let's say UNESCO now has this vision of world peace. It's kind of how to link all that to your daily work, right, but in the end that you really want to help improve people's lives [recording unclear]. So that maybe sounds, - I'm not saying that to please you or something, but it is really something that I and my colleagues believe in. And it's something that's difficult to see for others. People don't care ... they go nine to five, it's their job that they're doing, they don't care. But there are a lot of people that really believe in what they do, and they hope that what they do contributes to the work that is making the world a better place. And in my case I was lucky to do something that I love, and that I also can feel that maybe it will help somebody in the end. (UNESCO 1)

The next and final section of this article considers the insight resulting from the research presented above that effective transnational governance requires three essential elements: a common language; an adherence to organisational cultures and values; and a personal commitment to transnationalism and one's own values. In this context, numbers can serve simultaneously both as doxa, i.e. the linguistic and thought-based infrastructure that can power the machinery of global governance, and - paradoxically - offer the "margin of freedom" and "degree of play" (Bourdieu 2000 , p. 234) that the construction of a utopian world - built on numbers - requires. Actors, like the interviewee above, assume different, interlinked identities in this game; they are prophets, using their expertise to forecast the future; they are saviours, working for organisations that proclaim their very existence as servants of those in need; and they are saints, since it is their morality that keeps them in a game which, despite being futile, is the only one to play. 


\section{Discussion}

In this article, I have used the Bourdieusian theoretical frame to analyse the construction of the machinery driving the 2030 Education Agenda (SDG 4), paying particular attention to the role of quantification as symbolic governance. I have made particular use of Bourdieu's concepts of field and symbolic capital, with symbolic referring on the one hand to the accumulation of a range of capitals at the disposal of actors operating in the metrological field, but also, on the other hand, to all those other, perhaps more material, manifestations of distinction and power, such as the use of evocative language, beautiful data, marathon sessions, and Global South participants flown around the world. A significant source of evidence for this article is documents, but crucially I also drew on actors' own accounts, as they described "horizontal" relations of cooperation, competition and conflict of the kind that take place at that level of the transnational.

In order to make sense of the use of numbers as symbolic governance, one needs to highlight the main characteristics of SDG 4, as well as its differences from previous similar initiatives. For a start, SDG 4 could be seen as a prime example of a transnational soft regulatory instrument (in the tradition of "soft" law, i.e. best practices, expert standards, rankings, ratings, audits, quality assurance and the like). As such, it creates competitive and reputational pressures on those participating - by participants here I do not mean just country representatives, but also actors who work in the field, from the different IOs, research agencies and civil society. Similar to many other global monitoring tools, the Education 2030 Agenda (SDG 4) is interventionist in nature, leading effectively to a mutually constitutive relationship of the statistics and the countries they are meant to represent.

However, this article has also extensively discussed the ways in which SDG 4 is substantially different from other quantification exercises. The construction of SDG 4 represents a leap in the practice of transnational soft regulation in education because, although prescriptive, it also appears as transparent, pluralistic, open and developmental - consensus-making is prioritised and data collection and validation processes are required to be "democratic". I have described the ways in which the centrifugal forces of technical and political accountability have given shape to the metrological field and the different actors' positionings and political work within it.

At the heart of this article are the paradoxes and the multiple ambivalences that quantification brings to the building of the transnational metrological field in education. On the one hand, they are necessary for the construction of discursive coalitions of actors who are not known to each other or have not collaborated before. The indicator framework and all other subsets of numerical work create what Bourdieu (1977) terms a "linguistic market". While some actors have the epistemic purchase to own and control most of this market, many others, as we have seen, are there - knowingly and willingly - to consume this lingua franca of numbers and transport it back home. Second, numbers' underlying use as the new doxa of transnational governance legitimates a whole series of informal and ad hoc arrangements, all accepted and all approved in the name of an education crisis and the need to 
construct as broad a consensus as possible; in this fluid and dynamic arena, even bad quality data or even no data would do.

Further, as we have seen above, SDG 4 identifies a specific failure of all previous statistical large-scale projects to deliver equitable education and develops a manifest governing programme to influence the behaviour of the participating actors. It may be that interventions still appear restricted to pushing (and largely financing) the statistical capacity for nations to produce data for governing; nevertheless this step is seen as (and indeed is) key in achieving "transformative" change. Thus, this article examines the promotion of SDG 4 as the emergence of a metrological field that transcends national/international/state/non-state divides. Crucially, this is not a governing structure that sits "on top of" national and local decision-making, but has the very explicit aim of achieving national agendas capable of replacing current policies with ones which will deliver on the targets of SDG 4.

Nevertheless, these processes are not smooth and linear. As the empirical material shows, they involve antagonistic relationships of all the actors involved, and increasingly so, given the universal aspirations of the agenda and its claims to "democratise" data monitoring for all the participant nations. Lack of resources creates enormous frustrations and limitations; in many ways it necessitates the use of pre-existing data. This creates pressures in the relationships of the four major IOs (UNESCO, OECD, UNICEF and the World Bank), since they have to coordinate their work in a context not only restricted by limited budget availability, but also under conditions of attacks on their expertise. How is one to make sense of how this complex infrastructure of transnational governance comes into being? In other words, in conditions where the field to be governed is fluid and constantly shifting, how is one to analytically explain how these multi-party, polycentric, transnational and often inter-cultural networks of governance function?

Following previous research of the European Union (EU) on field theory and governance (Kauppi 2003), this article argues that applying Bourdieu's concept of a field to the mechanisms at work in the metrological field concerned with SDG 4 indicators allows for an investigation of "horizontal" relationships of interdependence and interaction of organisational actors which goes beyond "top-down" and "bottom-up" understandings of the national/global relationship. The ambiguity of numbers which describe and simultaneously prescribe allows participant actors to perform their function as transnational actors who can simultaneously take part in collective decision-making and maintain their own particular register of the meeting and its aims and decisions. In this metrological space or field, objective relations are structured by the distribution of economic, epistemic or cultural resources "which are or may become active, effective, like aces in a game of cards, in the competition for the appropriation of scarce goods of which this social universe is the site" (Bourdieu 1989, p. 17). The perceived weak positioning of Global South actors in the process is a telling example of this.

Although the non-existence of any "rules of the game" in this field is often seen in the literature as an "institutional void" (Hajer 2003), where actors have to make up the rules and processes as they go along, this article suggests that quantification is precisely the necessary underlay in the construction of a relatively stable metrological field where an emblematic issue, such as equal and quality education for all, 
brings actors together in an almost religious mission with strong moral undertones. Statistical knowledge in this instance, in the form of the specific targets and indicators constructed, despite being scarce, contested and sometimes altogether absent, still fulfils a key role in symbolically representing a much larger and complex political problem and serves to unite actors in the quest for "solutions". Numbers, therefore, function as a form of symbolic governance that brings together the particular national and organisational storylines, the actors that employ them and the practices they apply to exert their influence in the metrological field.

Thus, quantification is key in the production of transnational governance, as it represents the unfolding development of "product and process", constantly moving with that which it seeks to move. Instead of seeing SDG 4 as solely a process of depoliticising education through the imposition of a measurement agenda, the Bourdieusian perspective allows its examination as a process of re-politicisation of education problems by making them knowable and actionable according to the new quantitative symbolic order imposed. By using the notion of "symbolic governance", this article has brought to the fore the "acts of performative magic" (Bourdieu 2000, p. 243) that continue to build this governing infrastructure, attending to the power play, ideas and values which infuse the everyday realities inhabited by IOs. SDG 4, as "product and process", despite all its contestations and failings, shapes that which it classifies, measures and seeks to order. This article shows how SDG 4 generates particular scripts of action and reconfigures education problems and issues in ways that invite certain possibilities for deliberation and intervention at the expense of others.

Acknowledgements This article is part of a project that has received funding from the European Research Council (ERC) under the European Union's Horizon 2020 research and innovation programme, under Grant agreement No 715125 METRO (ERC-2016-StG) ("International Organisations and the Rise of a Global Metrological Field”, 2017-2022, PI: Sotiria Grek). I would also like to add my thanks to Matteo Ronzani, Justyna Bandola-Gill, Marlee Tichenor and Anke Grotlüschen for their helpful comments and advice on previous versions of this article, as well as to Maya Kiesselbach for her meticulous editing efforts.

Open Access This article is licensed under a Creative Commons Attribution 4.0 International License, which permits use, sharing, adaptation, distribution and reproduction in any medium or format, as long as you give appropriate credit to the original author(s) and the source, provide a link to the Creative Commons licence, and indicate if changes were made. The images or other third party material in this article are included in the article's Creative Commons licence, unless indicated otherwise in a credit line to the material. If material is not included in the article's Creative Commons licence and your intended use is not permitted by statutory regulation or exceeds the permitted use, you will need to obtain permission directly from the copyright holder. To view a copy of this licence, visit http://creativecommons.org/licen ses/by/4.0/.

\section{References}

Alasuutari, P., Rautalin, M., \& Syväterä, J. (2016). Organisations as epistemic capital: The case of independent children's rights institutions. International Journal of Politics, Culture, and Society, 29(1), 57-71. https://doi.org/10.1007/s10767-015-9205-3.

Alonso, W., \& Starr, P. (Eds.). (1987). The politics of numbers. New York: Russell Sage Foundation. 
Bhuta, N. (2012). Governmentalizing sovereignty: Indexes of state fragility and the calculability of political order. In K. Davis, B. Kingsbury, \& S. Merry (Eds.), Indicators as technologies of global governance (pp. 132-164). Oxford: Oxford University Press.

Bogdandy, A., Dann, P., \& Goldmann, M. (2008). Developing the publicness of public international law: Towards a legal framework for global governance activities. German Law Journal, 9, 1375-1400.

Bourdieu, P. (1977). Outline of a theory of practice. Cambridge: Cambridge University Press.

Bourdieu, P. (1986). The forms of capital. In J. G. Richardson (Ed.), Handbook of theory and research for the sociology of education (pp. 241-258). Westport, CT: Greenwood Press.

Bourdieu, P. (1989). Social space and symbolic power. Sociological Theory, 7(1), 14-25.

Bourdieu, P. (1990). The logic of practice. Stanford, CA: Stanford University Press.

Bourdieu, P. (1993). The field of cultural production. Cambridge: Polity Press.

Bourdieu, P. (2000). Pascalian meditations. Stanford, CA: Stanford University Press.

Bourdieu, P. (2014). On the state: Lectures at the College de France. Cambridge: Polity Press.

Bourdieu, P., \& Wacquant, L. J. D. (1992). An invitation to reflexive sociology. Chicago, IL: University of Chicago Press.

Bowker, G., \& Star, S. L. (1999). Sorting things out: Classification and its consequences. Cambridge, MA: MIT Press.

Chouliaraki \& Fairclough. (1999). Discourse in late modernity: Rethinking critical discourse analysis. Edinburgh: Edinburgh University Press.

Crump, T. (1990). The anthropology of numbers. Cambridge: Cambridge University Press.

Desrosieres, A. (1998). The politics of large numbers: A history of statistical reasoning. Cambridge, MA: Harvard University Press.

Djelic, M.-L., \& Sahlin-Andersson, K. (Eds.). (2006). Transnational governance: Institutional dynamics of regulation. Cambridge: Cambridge University Press.

Dodds, F., Donohue, D., \& Roesch, J. (2017). Negotiating the sustainable development goals. London: Earthscan.

Espeland, W., \& Stevens, M. L. (2008). A sociology of quantification. Archives Europeennes de Sociologie, 49(3), 401-436. https://doi.org/10.1017/S0003975609000150.

Fisher, A., \& Fukuda-Parr, S. (2019). Introduction: Data, knowledge, politics and localizing the SDGs. Journal of Human Development and Capabilities, 20(4), 375-385. https://doi.org/10.1080/19452 829.2019.1669144.

Fougner, T. (2008). Neoliberal governance of states: The role of competitiveness indexing and benchmarking. Millennium: Journal of International Studies, 37(2), 303-326. https://doi. org/10.1177/0305829808097642.

Fukuda-Parr, S. (2016). From the millennium development goals to the sustainable development goals: Shifts in purpose, concept, and politics of global goal setting for development. Gender and Development, 24(1), 43-52. https://doi.org/10.1080/13552074.2016.1145895.

Fukuda-Parr, S., \& McNeil, D. (2019). Knowledge and politics in setting and measuring the SDGs: Introduction to special issue. Global Policy, 10(1), 5-15. https://doi.org/10.1111/1758-5899.12604.

Geertz, C. (1980). Negara: The theatre state in nineteenth-century Bali. Princeton, NJ: Princeton University Press.

Giddens, A. (1985). The nation-state and violence. A contemporary critique of historical materialism, vol. 2. Berkeley, CA: University of California Press.

Grek, S. (2009). Governing by numbers: The PISA effect in Europe. Journal of Education Policy, 24(1), 23-37. https://doi.org/10.1080/02680930802412669.

Grek, S. (2016). Expert moves: International comparative testing and the rise of expertocracy. In B. Lingard, W. Martino, \& G. Rezai-Rashti (Eds.), Testing regimes, accountabilities and education policy (pp. 157-171). Abingdon: Routledge.

Grek, S. (2020a). Numbers as symbolic governance. METRO, 14 February [blogpost]. Retrieved 3 June 2020 from http://www.metro-project.eu/symbolic-governance/.

Grek, S. (2020b). Interdependency in education governance. In G. Fan \& T. Popkewitz (Eds.), Handbook of education policy studies: Values, governance, globalisation, and methodology (Vol. 1, pp. 309-328). Singapore: Springer. https://doi.org/10.1007/978-981-13-8347-2_14.

Guadalupe, C. (2017). Standardisation and diversity in international assessments: Barking up the wrong tree? Critical Studies in Education, 58(3), 326-340. https://doi.org/10.1080/17508487.2017.13403 19.

Hacking, I. (1990). The taming of chance. Cambridge: Cambridge University Press. 
Hacking, I. (2007). Kinds of people: Moving targets. Proceedings of the British Academy, 151, $285-318$. https://doi.org/10.5871/bacad/9780197264249.003.0010.

Hajer, M. (2003). Policy without polity? Policy analysis and the institutional void. Policy Sciences, 36(2), 175-195. https://doi.org/10.1023/A:1024834510939.

Hansen, K., \& Porter, T. (2012). What do numbers do in transnational governance? International Political Sociology, 6(4), 409-426. https://doi.org/10.1111/ips.12001.

Higgins, V., \& Larner, W. (Eds.). (2010). Calculating the social: Standards and the reconfiguration of governing. Basingstoke: Palgrave Macmillan.

Jullien, B., \& Smith, A. (2008). Introduction: Industries, globalization and politics. In B. Jullien \& A. Smith (Eds.), Industries and globalisation: The political causality of difference (pp. 1-28). Basingstoke: Palgrave Macmillan.

Kauppi, N. (2003). Bourdieu's political sociology and the politics of European integration. Theory and Society, 32(5/6), 775-789.

Lagroye J. (1997). Sociologie politique [Political sociology]. Paris: Presses de la Fondation nationale des sciences politiques (FNSP) and Dalloz.

Lampland, M., \& Starr, S. L. (Eds.). (2009). Standards and their stories. How quantifying, classifying and formalizing practices shape everyday life. Ithaca, NY: Cornell University Press.

Latour, B. (1987). Science in action: How to follow scientists and engineers through society. Cambridge, MA: Harvard University Press.

Latour, B. (2005). Reassembling the social: An introduction to actor-network-theory. Oxford: Oxford University Press.

Martens, K. (2007). How to become an influential actor: The comparative turn in European educational policy. In K. Martens, A. Rusconi, \& K. Leuze (Eds.), New arenas of education (pp. 40-56). Basingstoke: Palgrave Macmillan.

Merry, S. E. (2011). Measuring the world: Indicators, human rights, and global governance. Current Anthropology, 52(S3), S83-S95. https://doi.org/10.1086/657241.

Merry, S.E. (2019). What is counted and what counts? The infrastructure of measurement and the SDGs (under review with Law \& Society Review; draft on file with editors).

Palan, R. (2006). The offshore world: Sovereign markets, virtual places, and nomad millionaires. Ithaca, NY: Cornell University Press.

Porter, T. (1995). Trust in numbers: The pursuit of objectivity in science and public life. Princeton, NJ: Princeton University Press.

Power, M. (1997). The audit society: Rituals of verification. Oxford: Oxford University Press.

Rose, N. (1999). Powers of freedom: Reframing political thought. Cambridge: Cambridge University Press.

Saetnan, A. R., Lomell, H. M., \& Hammer, S. (Eds.). (2011). The mutual construction of statistics and society. London: Routledge.

Sauder, M., \& Espeland, W. (2009). The discipline of rankings: Tight coupling and organizational change. American Sociological Review, 74(1), 63-82. https://doi.org/10.1177/000312240907400104.

Shore, C., \& Wright, S. (2015). Audit culture revisited: Ratings, rankings and the reassembling of society. Current Anthropology, 56(3), 421-444. https://doi.org/10.1086/681534.

Stiglitz, J.E., Sen, A., \& Fitoussi, J.-P. (2009). Report by the Commission on the Measurement of Economic Performance and Social Progress. Paris: Commission on the Measurement of Economic Performance and Social Progress (CMEPSP). Retrieved 1 June 2020 from http://files.harmonywithnatu reun.org/uploads/upload112.pdf.

Strathern, M. (Ed.). (2000). Audit cultures: Anthropological studies in accountability, ethics and the academy. London: Routledge.

Swartz, D. (2013). Symbolic power, politics and intellectuals: The political sociology of Pierre Bourdieu. Chicago, IL: University of Chicago Press.

UIS (UNESCO Institute for Statistics). (2016). Laying the foundation to measure Sustainable Development Goal 4. Sustainable development data digest. Montreal: UNESCO Institute for Statistics. Retrieved 9 June 2020 from https://unesdoc.unesco.org/ark:/48223/pf0000245559.

UN (United Nations). (2015). Sustainable Development Goal 4: Ensure inclusive and equitable quality education and promote lifelong learning opportunities for all, targets and indicators [dedicated webpage]. Sustainable Development Goals knowledge platform [online resource]. Retrieved 7 June 2020 from https://sustainabledevelopment.un.org/sdg4. 
UN (2020). Tier classification for global SDG indicators as of 17 April 2020. New York: United Nations Statistics Commission (UNSC). Retrieved 9 June 2020 from https://unstats.un.org/sdgs/files/ Tier\%20Classification\%20of\%20SDG\%20Indicators_17\%20April\%202020_web.pdf.

UNESCO (United Nations Educational, Scientific and Cultural Organization). (2014). 2014 GEM Final Statement: The Muscat agreement. Final statement agreed at the Global Education for All (EFA) meeting held 12-14 May 2014 in Muscat, Oman. ED-14/EFA/ME/3 REV. Paris; UNESCO. Retrieved 19 November 2019 from https://unesdoc.unesco.org/ark:/48223/pf0000228122.

UNESCO (2016a). Education 2030. Incheon declaration and Framework for action for the implementation of Sustainable Development Goal 4: Ensure inclusive and equitable quality education and promote lifelong learning. ED-2016/WS/28. Paris: UNESCO. Retrieved 7 June 2020 from https://unesd oc.unesco.org/ark:/48223/pf0000245656.

UNESCO. (2016b). Unpacking Sustainable Development Goal 4: Education 2030 - guide. Paris: UNESCO. Retrieved 9 June 2020 from https://unesdoc.unesco.org/ark:/48223/pf0000246300.

UNESCO. (2019). SDG-Education 2030 Steering Committee: List of members 2019-2020. Paris: UNESCO. Retrieved 9 June 2020 from https://www.sdg4education2030.org/list-sdg-education-2030steering-committee-members-2019-2020-december-2018.

Ydesen, C., \& Grek, S. (2019). Securing organisational survival: A historical inquiry into the OECD's work in education during the 1960s. Paedagogica Historica. https://doi.org/10.1080/00309 230.2019.1604774.

Publisher's Note Springer Nature remains neutral with regard to jurisdictional claims in published maps and institutional affiliations.

Sotiria Grek is Senior Lecturer in Social Policy at the School of Social and Political Science, University of Edinburgh. She works on education policy, transnational policy learning, the politics of quantification, knowledge and governance. She is the Principal Investigator of the "International Organisations and the Rise of a Global Metrological Field" (METRO) project funded by the European Research Council. She has co-authored (with Martin Lawn) Europeanising Education: Governing A New Policy Space (Symposium, 2012) and co-edited (with Joakim Lindgren) Governing by Inspection (Routledge, 2015), as well as the World Yearbook in Education: Accountability and Datafication in Education (with Christian Maroy and Antoni Verger; to be published by Routledge in 2021). 